\title{
Deviant Care: Chanson douce and the Killer Nanny
}

\author{
JULIE RODGERS
}

\begin{abstract}
This article examines the darker side of care as depicted in Leilla Slimani's Chanson douce (2016), an important aspect of the carer-caree relationship that has been much less documented than the positive nature of care-giving. The article traces the nanny's trajectory through different stages of care from early feelings of attachment and devotion to a point of crushing fear, unmanageable anxiety and overwhelming exhaustion, which then leads her onto a path of incremental abuse. Rather than focusing on the actual crime committed (infanticide), the article endeavours to understand the nanny's personal circumstances and the way in which they inflect her care-giving and ultimately steer it towards a deviant turn. The overall aim of the article is to demonstrate that the reality of care is much more complex than one might realize (especially when it is caught up in the gruelling ideals of perfect motherhood) and more often than not co-exists alongside various forms of abuse, which in the case of Chanson douce, culminate in tragedy.
\end{abstract}

\section{Care and the nanny question}

According to Koggel and Ormes, ${ }^{1}$ ever since Carol Gilligan's call for a system of moral reasoning based on an ethics of care in her foundational publication In a Different Voice (1982), ${ }^{2}$ there has been a marked turn towards the increased development of both care theory and praxis, not only within the social sciences, as one might expect, but also in an impressive range of academic disciplines. However, as noted by Koggel and Ormes, research trends thus far, particularly in relation to the arts and humanities and, more specifically, literature, have veered significantly in the direction of ethical reflections on care and less on its application and quotidian reality. Moreover, many of these discussions tend to centre on the positivity of the care perspective and its potential to create a more inclusive, engaged and attentive society. This article offers an alternative perspective on the exploration of care in literature by taking as its focal points the following: first, the

\footnotetext{
${ }^{1}$ Christine Koggel and Joan Orme, "Care Ethics: New Theories and Applications", Ethics and Social Welfare, 4: 2 (2010), 109-114.

${ }^{2}$ Carol Gilligan, In a Different Voice: Psychological Theory and Women's Development (Cambridge, MA: Harvard University Press, 1982).
} 


\section{Julie Rodgers}

actual practice of caregiving in all its intricacies and mundanities and, second, the darker side of care, that is, the one that emerges when it transgresses into deviance and leads to a devastating outcome for both carer and caree.

The particular type of caregiving that will be examined in detail in this article relates to mother-work, or rather, the ongoing care of children and attending to their every need, physical and emotional. Such work does not necessarily always fall to the actual mother (biological, adoptive or otherwise) but is often the responsibility of another woman (a nanny or an au-pair, for example) invited into the home and remunerated (albeit poorly in many instances) for her labour. Despite their ubiquitous presence over the course of several centuries across the world in middleto upper-class households and, today, their quasi-indispensability to professional career women, as Susan Scheftel observes, there has been "a pervasive omission of nannies" as a singular topic of exploration. ${ }^{3}$ Scheftel labels this widespread absence of curiosity about the overall phenomenon of in-home substitute care an "arguable scotoma" in the cultural imagination and goes on to explain the invisibility of nannies as being inextricably linked to their position as a site of conflict and guilt between mother and child. ${ }^{4}$ However, Leïla Slimani's Chanson douce, the novel that will serve as the subject of analysis in this article, places the nanny, her complex subjectivity as well as the realities of the profession, at the heart of its narrative. ${ }^{5}$

Published in August 2016 by Gallimard, Slimani's second novel received overwhelming critical acclaim and was promptly selected as the winner of the Prix Goncourt in November of the same year. As Diana Holmes has noted, the award of the Prix Goncourt led to a substantial shift in the nature and scale of the readership of Chanson douce. What might otherwise have been passed over as a challenging and, indeed, distressing novel suddenly became a middlebrow, best-selling page-turner. ${ }^{6}$ By 2018, two English versions of the text had been produced (The Perfect Nanny and Lullaby in the USA and the UK respectively) as well as translations into eighteen other languages, with seventeen others planned. The resounding success of the novel has also led to its adaptation in 2019 for the stage (Pauline Bayle) and screen (Lucie Borleteau), although, for various reasons, both productions have been less favourably received than the original text. Curiously, however, despite the considerable and farreaching recognition enjoyed by Chanson douce and, furthermore, its prestigious literary credentials, to date the novel has not received extensive academic discussion.

3 Susan Scheftel, “Why Aren't We Curious About Nannies”, The Psychoanalytic Study of the Child, 66: 1 (2012), 252-278 (p. 252).

${ }^{4}$ Ibid., p. 252.

${ }^{5}$ Leïla Slimani, Chanson douce (Paris: Gallimard, 2016). Henceforth, references to this work are given in the body of the text.

${ }^{6}$ Diana Holmes, "Femmes et prix littéraires", in Ángeles Ciprés Palacín and Isabelle Marc (eds), Canon et écrits de femmes en France et en Espagne dans l'actualité (2011-2016) (Bern: Peter Lang, 2020), pp. 31-47. 
This may be due in part to the difficult subject matter of the novel, that is, a narrative of care, trust and love that mutates into the gruesome act of infanticide. ${ }^{7}$ As such, among the sparse scholarly work on Chanson douce, there is a keener analysis of the politics of immigration ${ }^{8}$ and issues of postcolonialism and transnationalism ${ }^{9}$ in the novel than of care-giving and mother-work. And yet, reviews of Chanson douce clearly direct our attention towards the nanny question: for example, Edemariam describes it as "a political book about emotional work, about women and children and their costs and losses"10, and Howell remarks that Slimani's prose is focused "less on the murder of Mila and Adam [the children] than on the psychological complexity of the accused [...] her vulnerabilities and perplexities as a character". ${ }^{11}$

This article aims to delve more deeply into both the public and private worlds of the nanny in Chanson douce in a bid to understand (but not unequivocally to empathize with) the eventual mutation of her care from devoted to deviant. It will consider what is often referred to in care literature as "caregiver burden" 12 and the "caregiving stress process". ${ }^{13}$ Both phenomena are closely interlinked and encompass the objective/material and subjective/affective aspects of care-work. By "caregiver burden" I invoke the overwhelming demands and expectations placed on the carer on a daily basis, and by "stress process" I refer to the range of intrapsychic and situational circumstances that can negatively affect the caregiving experience. In the case of Chanson douce, it is useful to think of "caregiver burden" in terms of the ideals of intensive mothering at play in the novel as well as the isolating and repetitive nature of mother-work to which the nanny is subjected, with the stress factors ranging from economic/class and individual background history to personality, mental health and, more generally, the derisive treatment of nannies in society.

\footnotetext{
7 Although technically the term infanticide refers to the killing of a child by its mother, I expand the use of the term here to include those who carry out mother-work.

${ }^{8}$ Khalid Lyamlahy, "On the Imperfections of the Perfect Nanny", 2018, <https://www. worldliteraturetoday.org/blog/book-reviews/imperfections-perfect-nanny-khalid-lyamlahy>, accessed 01/02/20.

${ }^{9}$ Lorenza Starace, "Leïla Slimani’s Chanson douce: Paradoxes of Identity and Visibility in the littérature-monde Paradigm", Francosphères, 8: 2 (2019), 143-165.

${ }_{10}$ Aida Edemariam, "Review of Lullaby", 2018, <https://www.theguardian.com/books/2018/ jan/10/lullaby-leila-slimani-review>, accessed 31/01/2020.

${ }^{11}$ Jennifer Howell, "Review of Chanson douce", Journal of North African Studies, 22: 2 (2017), 301-303 (p. 301).

${ }^{12}$ Kuei-Ru Chou, "Caregiver Burden: A Concept Analysis", Journal of Paediatric Studies, 15: 6 (2000), 398-407.

${ }^{13}$ Leonard Pearlin et al., "Caregiving and the Stress Process: An Overview of Concepts and their Measures", The Gerontologist, 30 : 5 (1990), 583-594.
} 


\section{Killer nannies}

Rather than gently guiding the reader towards the final denouement, the ironically titled Chanson douce opens with the brutal stabbing of two young children by their nanny Louise and the latter's own attempted suicide. ${ }^{14}$ Through a process of analepsis, Slimani then traces backwards through the narrative to explore the family background, the arrival of the nanny, the relationship between the carer and the carees, the individual circumstances of the nanny and the gradual disintegration of the caregiving, culminating in tragedy. As confirmed by the author herself in several interviews, the events of the novel are inspired by the real-life and heavily mediatized killing of the Krim siblings by their nanny Yoselyn Ortega in a New York apartment in $2012 .{ }^{15}$ There is also a nod, however, to an earlier case of "nanny crime" through the choice of Louise as the forename of the fictional nanny of Chanson douce, which reminds the reader of Louise Woodward, the British au-pair convicted of manslaughter in the state of Massachusetts (USA) in 1997. However, in contrast to the media coverage of the above crimes that concentrated on the outright demonization of the "killer nanny" as unnatural and pathological, Chanson douce presents a more nuanced portrait of the nanny; without condoning the murder, it calls on the reader to consider the strains and pressures that may have pushed the protagonist to commit such a heinous crime. As Natalie Edwards points out in her article "Obliged to Sympathise", inviting empathy towards a murderer of children and, more specifically, an intimate female carer of children, is far from straightforward, because infanticide invokes so many unfathomable cultural and societal taboos concerning the nature of mother-work. By biological prescription, Edwards writes, "women are givers of life, not takers of it. Such a crime [infanticide] confronts the notion that women desire, nurture, protect and love their children instinctively and it testifies to the propensity of women to commit violence". ${ }^{16}$ Lisa Downing makes a similar observation, explaining that the infanticidal mother-figure transgresses "not only morality, compassion and the law but also the unwritten but powerful and

${ }^{14}$ It is worth noting that "Une chanson douce" (also known as "Le Loup, la Biche et le Chevalier") is a popular French children's lullaby written by Maurice Pon in the 1950s. The lyrics make direct reference to the mother figure: "Une chanson douce/que me chantait ma maman/en suçant mon pouce/j'écoutais en m'endormant." The lullaby alludes to the care and tenderness of the mother as she gently sings her child to sleep for the night. In the case of Chanson douce the novel, however, the "putting to sleep" of the children is much more brutal and finite through the act of murder.

${ }_{15}$ For example, see Slimani's interview with Anna Silman for The Cut, April 2018, <https:// www.thecut.com/2018/04/perfect-nanny-author-leila-slimani-on-new-york-nanny-trial.html>, accessed 13/02/2020.

${ }^{16}$ Natalie Edwards, “Obliged to Sympathise: Infanticide in Il y a longtemps que je t'aime and $\dot{A}$ perdre la raison”, Australian Journal of French Studies, 52: 2 (2015), 174-187 (p. 174). 
binding social rule of what it is supposed to mean to be a woman". ${ }^{17}$ This, Downing explains, is our "dearly held cultural myth that all women instinctively love and seek to protect children". ${ }^{18}$ And yet, despite the challenge posed by the subject matter, as Kathryn Robson notes, Chanson douce is not an isolated text in the field of contemporary women's writing in French in its exploration of infanticide. On the contrary, Robson writes, "whilst narratives of child death unsurprisingly typically figure unthinkable traumatic loss that is difficult to articulate [...] infanticide seems surprisingly almost too easily recounted and understood in contemporary French writing" ${ }^{19}$ What is more, Robson adds, "these representations of maternal filicide are strikingly bound up in and framed by claims of empathy". ${ }^{20}$

\section{Mother-work}

In the case of Chanson douce, it is Slimani's intricate unpicking of the realities of caregiving and mother-work that incites reflection on what might compel someone to commit "a seemingly unspeakable atrocity like infanticide". ${ }^{21}$ It is well documented by feminist and motherhood scholarship that the work of mothering has long been subject to ideologies of intense attachment and self-abnegation. However, as recent publications have observed, the twenty-first century has produced some of the most demanding and debilitating models of mother-work thus far. For example, Douglas and Michaels draw our attention to the phenomenon of "new momism", a set of motherhood norms and practices that insists "that to be a remotely decent mother, a woman has to devote her entire physical, psychological, emotional and intellectual being, 24/7, to her children". ${ }^{22}$ At the same time, Douglas and Michaels note, despite the arduousness of their daily responsibilities, mothers are expected to view their care labour solely as a positive and fulfilling experience. There is no place for the inner conflicts and maternal ambivalence that Rozsika Parker informs us are much more "natural" features of the work of mothering than the presumption of "unstinting love" and "unalloyed pleasure in children". ${ }^{23}$ According to Elisabeth Badinter, the cultural pervasiveness of such glorifying images of motherhood largely explains why mothers are ill-prepared for the challenges of the mother-work that awaits them.

${ }^{17}$ Lisa Downing, The Subject of Murder: Gender, Exceptionality and the Modern Killer (Chicago: University of Chicago Press, 2013), p. 107.

${ }^{18}$ Ibid., p. 108.

19 Kathryn Robson, I Suffer, Therefore I Am: Engaging with Empathy in Contemporary French Women's Writing (Oxford: Legenda, 2019), p. 73.

${ }^{20}$ Ibid., p. 73.

${ }^{21}$ Ibid., p. 91.

${ }^{22}$ Susan Douglas and Meredith Michaels, The Mommy Myth: The Idealization of Motherhood and How It Has Undermined Women (New York: Free Press, 2004), p. 4.

${ }^{23}$ Rozsika Parker, Torn in Two: The Experience of Maternal Ambivalence (London: Virago, 2005), p. 26. 
Badinter also recognizes that "la maternité, plus que dans le passé représente un travail à plein temps". ${ }^{24}$

It is clear from the outset in Chanson douce that the myth of motherhood does not correspond to the lived experience. As such, Myriam (the biological mother who chooses to hire the nanny in the novel) struggles with the changes that motherhood brings into her life and that she was not expecting to be quite so brutal: "Elle ne mesurait pas l'ampleur de ce qui s'annonçait. Avec deux enfants tout est devenu plus compliqué" (p. 19). In contrast to the promises of joy and absolute fulfillment, there is a marked deterioration in Myriam's mood. She is described as "assombrie" (p. 19), "désespérée" (p. 23) and "abattue" (p. 23). She begins to resent the children and their constant needs and increasingly feels "le besoin de marcher seule" (p. 19). Even stronger, however, is Myriam's sense that she is being physically consumed and psychologically unhinged by mothering: "[E]lle avait envie de hurler comme une folle dans la rue. 'Ils me dévorent vivante', se disait-elle parfois" (p. 20). She compares mother-work to "une ancre qui entraîne vers le fond, qui tire le visage du noyé dans la boue" (p. 44) and the long days spent alone with the children are "interminables" (p. 19). This is not the first time that Slimani has directed the reader's attention to the more difficult side of motherhood. Like Myriam, Adèle, the protagonist of Dans le jardin de l'ogre, experiences caring for her son as "une contrainte dont elle a du mal à s'accommoder" which gives rise to a tornado of "sentiments confus" comprising of "panique", "agacement" and "épuisement". ${ }^{25}$ Again, in comparison with Myriam, "les journées à la maison lui semblaient interminables". ${ }^{26}$

As the nanny employed by Myriam to carry out the work of mothering in her place while the latter reprises her career, Louise is no less subject to the pressures and stresses of this particular type of care-labour than the biological mother. As Cameron Lynne MacDonald observes in her study of au-pairs and nannies, the same impossible standards are demanded of those employed to care for children as of biological mothers themselves. MacDonald remarks that, just as the existence of "maternal instinct" is considered innate to all mothers, so too "nannies are expected to naturally love the children in their care". ${ }^{27}$ In addition to this, a major component of the nanny's role, MacDonald informs us, entails "restabilizing a view of family life that corresponds with intensive mothering ideals". ${ }^{28}$ This is exactly the case of Louise in Chanson douce, who, we are told, "suscite et comble les fantasmes de famille idéale que Myriam a honte de nourrir" (p. 35). Caroline Ibos develops this line of thought even further when she queries whether or not the mothers who hire

${ }^{24}$ Elisabeth Badinter, Le Conflit, la femme et la mère (Paris: Flammarion, 2010), p. 171.

${ }^{25}$ Leïla Slimani, Dans le jardin de l'ogre (Paris: Gallimard, 2014), p. 39.

26 Ibid., p. 41.

27 Cameron Lynne MacDonald, Nannies, Au-Pairs and the Micropolitics of Mothering (Berkeley: University of California Press, 2011), p. 111.

${ }^{28}$ Ibid., p. 109. 
nannies even truly view them as having a profession; instead, these mothers expect them to care for their children out of a sense of vocation: "L'employeuse hésite à qualifier l'activité de la nounou; il n'est pas certain qu'il s'agisse d'un vrai travail, car qu'est-ce qu'un travail qui consiste à donner de l'amour. [...] Aimer, et tous les gestes que cet amour suppose-nourrir, bercer, veiller...-n'est pas travailler." ${ }^{\prime 29}$ This, in turn, Ibos argues, is what leads to the poor remuneration of nannies for their carework: "[L]a vocation explique aux yeux de l'employeuse que la nounou accepte avec plaisir un travail mal payé: pour elle, l'argent compte moins que le désir de s'occuper de l'enfant.". ${ }^{30}$ While we are never explicitly told in Chanson douce what kind of salary Louise has been offered, what we do know is that she is unable to pay off her debts and remains in a state of financial precarity. Nor does her job seem to come with any specific terms, conditions or even boundaries. As such, when Louise begins to take on the housework as well as caring for the children, while Myriam may feel momentarily guilty, she does not object: "Myriam accepte de se faire materner. Chaque jour, elle abandonne plus de tâches à une Louise reconnaissante" (p. 59). As a result, there is a subtle exploitation of the nanny, which the latter facilitates through her desire to please her employers.

\section{Deviant care}

Given that the nanny is regulated by the same unwritten but widely accepted rules of mother-work, it is perhaps not surprising that a similar downturn in how caregiving is experienced can be observed not only in Myriam but also in Louise. What commences as a positive, gratifying, even rapturous caregiving exchange between Louise and the children soon gives way to the more negative and darker feelings experienced by Myriam. Louise begins to feel "enfermée dans l'appartement des Massé" (p. 112) and, not insignificantly, just like Myriam, "elle a parfois l'impression de devenir folle" (p. 112). The work of mothering is depicted as overwhelmingly monotonous, with the children insisting on "la répétition de tout, des histoires, des jeux, des grimaces, et Louise n'en peut plus" (p. 212). In addition, like many types of intensive caregiving, mother-work also besets the nanny with "un sentiment de solitude immense" (p. 112), a point that is reiterated later in the novel when Slimani writes, "On se sent seul auprès des enfants. Ils se fichent des contours de notre monde" (p. 210).

The similar reactions of biological mother and nanny to the burden of their care-caregiving do not end here, for both begin to engage in deviant behaviour. Where Myriam is concerned, there is an unforeseen turn towards shoplifting as a

${ }^{29}$ Caroline Ibos, Qui gardera nos enfants? les nounous et les mères (Paris: Flammarion, 2012), pp. 38-39. The notion of mother-work as a "natural vocation" is also raised by Lisa Downing in her most recent publication, Selfish Women (London: Routledge, 2019), p. 124. Downing laments that women, from birth, are encouraged to imagine themselves as intimately connected to and responsible for the care of the other.

${ }^{30}$ Ibos, p. 39. 
possible form of escape from the drudgery of mother-work (p. 21). For Louise, the deviance takes the form of intermittent moments of abuse: frightening the children by hiding from them, sudden outbursts of anger and increasingly intrusive violent thoughts and desires such as "l'envie de poser ses doigts autour du cou d'Adam et de le secouer jusqu'à ce qu'il s'évanouisse" (p. 213). The point to be made here is that when the care-burden is experienced as unremittingly onerous, the potential for deviance is substantial. The boundary between "good care" and "bad care" is presented as porous, with positive actions all containing the potential to digress into something more negative. Often, the carer is not even aware that the threshold between "good" and "bad" has been crossed and that they have entered into a realm where their intended care is tinged with violence. One particular scene from the novel comes to mind here, where Myriam is in the bath with her infant son Adam: "Elle le tient entre ses cuisses, le serre contre elle au point qu'Adam finit par se débattre et par pleurer" (p. 125). Obviously, in the case of Louise, the transgression from "good" care to "bad" care ultimately becomes much more sinister as it culminates in the murder of the two children in her care who, ironically, as we are told at several points in the novel, are so adored by their nanny that it is as if "son bonheur leur appartient" (p. 81).

Without minimizing the atrocity that is committed by the nanny, there is also, however, the possibility of detecting an underlying gesture of care towards the children as they meet their tragic end. Louise calls to them softly, "Les enfants, venez, vous allez prendre un bain" (p. 227). It is worth noting here that the bath is a place where caregiving between nanny and child normally takes place through tender washing and bathing; hence, the children are invited by Louise into a space that they associate with positive care. This particular scene is reminiscent of the infanticidal mother of Joachim Lafosse's film $\dot{A}$ perdre la raison, ${ }^{31}$ who likewise gently invites her children upstairs one by one for a bath before stabbing them. ${ }^{32}$ Stabbing is also the mode of killing that is employed by Louise in Chanson douce. As Edwards argues in relation to $A$ perdre la raison, by contextualizing the crime and framing it within an oppressive discourse of motherhood, the film presents the viewer with "a compelling case for compassion" for the murderous mother. ${ }^{33}$ The narrative schema of Chanson douce is similar to that of $\dot{A}$ perdre la raison, opening with the crime having already been committed in secretum and then unravelling the diegesis retrospectively in a bid, it would seem, to incite an understanding of the desperation that the nanny has been driven to. Indeed, in an interview focusing on her adaptation of Chanson douce for theatre, Pauline Bayle discusses the possibility of interpreting the infanticide as a gesture of maternal care: "On peut se demander si par son acte ultime, Louise ne se

\footnotetext{
31 Joachim Lafosse (dir.), À perdre la raison, 2012.

32 One cannot help but note the metaphorical resonances of the bath/water image, which calls to mind the maternal womb/amniotic fluid and thus is associated with safety and nurture.

${ }^{33}$ Edwards, p. 176.
} 
substituera pas à la mère des enfants, opérant par cet arrachement l'apothéose d'un mouvement fusionnel amorcé dès son arrivée dans la famille."34

\section{The fantasy of perfection}

Before moving on from my analysis of the care-burden that is inherent to motherwork, the various external ideologies of motherhood that have a negative effect on the caregiving experience and, of course, the potential for such intensive caring to mutate into something darker, I would like to consider one further myth to which the nanny is subject but from which the biological mother escapes. The myth in question is that of the Mary Poppins phenomenon, the magical and inimitable figure from children's literature who has come to embody the perfect nanny. For Scheftel, "Mary Poppins provides a fascinating lens through which to contemplate the role of the nanny". ${ }^{35}$ Despite its seemingly innocuous presence in the popular imagination, it has gained such a foothold that, as Sheftel remarks, it is now "synonymous with the nannying enterprise in general". ${ }^{36}$ There is no doubt that the Mary Poppins phenomenon unconsciously shapes the expectations that the Massé couple has of their nanny in Chanson douce. Indeed, there are overt references: Louise is described as "cette nounou irréelle qui a jailli d'un livre pour enfants" (p. 62) and Paul proclaims that "elle a des airs de Mary Poppins" (p. 35). The arrival of Louise in the Massé household is compared to a bewitching "coup de foudre amoureux" ( $p$. 28). Louise quickly proves herself to be an exceptionally competent nanny, so much so that Myriam jokes that "il faut qu'elle ait des pouvoirs magiques" (p. 34). Louise is transformed from a regular nanny into a mystical figure, "une fée" (p. 34) and "la perle rare" (p. 35). Her employers imbue her with such a degree of otherworldliness that they presume her able to transcend all obstacles. Consequently, Myriam sees only Louise's surface imperturbability, "comme une mer paisible" (p. 29), and fails or perhaps refuses to recognize any of the anxieties or "abysses" (p. 29) that are hidden below. When Louise does not turn up for work one day, Myriam imagines all sorts of possible reasons other than the obvious one, sickness: "Comme si Louise était infaillible, que son corps ne pouvait connaître la fatigue ou la maladie" (p. 156).

The Mary Poppins myth that infiltrates and moulds the Massés perception of their nanny thus creates a further set of pressures in addition to the prescriptive norms and ideals of intensive mother-work that Louise must negotiate and prop up through her care. Unlike Myriam, whose return to her profession as a lawyer allows her to reconfigure herself as an individual outside of her mother-work, Louise has no outlet or space to partake in care for the self. And yet, as MacDonald asserts, it is vital that nannies have opportunities to speak and be heard, to retaliate and

\footnotetext{
34 See Pauline Bayle, <https://www.comedie-francaise.fr/en/news/...a-la-figure-du-monstreau-theatre\#>, accessed 13/02/2020.

35 Scheftel, p. 265.

${ }^{36}$ Ibid., p. 265.
} 
be comforted. MacDonald highlights the role played by the "park gatherings" in providing a forum for nannies to air their grievances and seek support. She states that these oft-impromptu meetings "serve the dual purpose of providing recognition for how hard childcare providers worked and reassuring them" ${ }^{37}$ as well as creating a sense of community. While Louise does frequent the park with the children, she does not socialize with the other nannies, apart from one (Wafa), and even then her interaction is brief and reluctant. Throughout the novel, Louise is associated with loneliness and isolation- "la solitude qui collait à sa chair, à ses vêtements" (p. 102). When we take into consideration the sheer extent of her care-burden, the monotony of her work, the unrealistic expectations of her employers, the constant needs of the children and her lack of a space for resistance, it would appear that the conditions are ripe for her to transgress the boundary between "good care" and "bad care".

\section{Care and the situational and intrapsychic factors}

In this final section, I will consider the combination of situational and intrapsychic factors that negatively affect Louise's caregiving. First of all, in relation to situation, it is important to consider the nanny's position both within the family and in society at large. For Ibos, the nanny is what she terms "une figure transfuge", ${ }^{38}$ that is, always moving between one place and another, between homes, from one family to the next. This constant to-ing and fro-ing in the life of a nanny, Ibos argues, leads to feelings of liminality, non-belonging and dislocation. In the case of Louise in Chanson douce, despite her "présence intime" (p. 59) in the Massé household, she is never fully integrated, "jamais familière" (p. 59), "une exilée" (p. 64). Related to the trope of liminality is the invisibility of the nanny in the eyes of her employers, who fail to see her as an individual outside her role as caregiver. Of Louise, it is remarked that "[o]n la regarde mais on ne la voit pas" (p. 59). Reinforcing this point concerning the invisibility of the nanny are the two fleeting moments when her employers, Paul and Myriam, suddenly see her as a person and are shocked at this realization. When on holidays with the Massé family and during a trip to the beach, Paul observes Louise outside their home, perhaps for the first time: "Une pensée idiote, fugace, lui vient et il en rit intérieurement: 'Louise a des fesses' [...]. Un corps qu'il n'avait ni vu ni même soupçonné, lui qui rangeait Louise dans le monde des enfants ou celui des employés" (p. 75). On another occasion, Myriam spots Louise from the car, walking through the streets of Paris: "Pour la première fois, elle tente d'imaginer, charnellement, tout ce qu'est Louise quand elle n'est pas avec eux" (p. 218). As Sheftel observes, this relegation of the nanny to "invisible status" is not uncommon: "On the one hand, these women are expected to perform significant aspects of a parent's job, but on the other hand, they are expected to remain background figures, whose presence

\footnotetext{
37 MacDonald, p. 145.

38 Ibos, p. 83.
} 
and necessity can be conveniently overlooked." 39 Tronto adds to the argument by stating that the nanny is essentially invisible in society because her role is confined to private rather than public space, the former being highly undervalued. She also calls attention to the fact that nannies, rather than being allowed to assert a sense of individuality, are expected to self-erase, to "reflect the values, tastes and other aspects of the lives of the employers". ${ }^{40}$ This would explain Paul's furious outburst when he returns home one evening to find that Louise has allowed Mila to play with the make-up that she herself wears every day (p. 106).

In addition to the nanny's invisibility both in the eyes of her employers and society more generally, is her devaluation, or, as Scheftel puts it, her "trivialization". ${ }^{4}$ Throughout Chanson douce, descriptions of Louise are inflected with an infantilizing rhetoric. She is compared to "une petite poupée" (p. 76), her slight, childlike frame is invoked regularly, and Paul speaks about her in her presence "comme on parle des enfants" (p. 66). Even the word "nounou", which is used to refer to Louise, is problematic despite its common usage as a form of endearment. Ibos states:

Le terme "nounou" porte en lui-même le mépris que la société voue à ces femmes. Supposée être l'abréviation enfantine du mot "nourrice", cette appellation soumet d'emblée l'employée au monde et aux désirs du jeune enfant. Comment une société peut-elle prendre au sérieux celles dont elles nomment le métier de manière si régressive? ${ }^{42}$

Not only does society not take these women seriously, it also shows no interest in listening to their voices. Louise's former husband would dismiss her accounts of her work-day as "affaires de bonnes femmes" (p. 99) and "il pensait que ces histoires ne sont pas bonnes à être racontées. Elles devraient être vécues à l'abri du monde, nous n'en devrions rien savoir" (p. 99). Finally, there is the treatment of the nanny as a commodity, an object to be chosen from a catalogue and purchased (p. 25). The squares and parks where the nannies gather to socialize and escape from the confines of the home are compared to market places where mothers come to peruse the labour on offer "comme autrefois on se rendait sur les docks ou au fond d'une ruelle pour trouver une bonne ou un manutentionnaire" (p. 201).

However, it is not just the external gaze that is responsible for creating the sense of inferiority and worthlessness harboured by Louise, there is her own personal situational history. We learn in the novel that her life has been one of constant care for others: of children, the elderly and her aggressive husband Jacques (who suffered from diabetes). This care, however, was rarely reciprocated. Over the course of her time as a carer, Louise has been hit, shouted at (p. 54), spat at and insulted (p. 109).

\footnotetext{
39 Scheftel, p. 623.

40 Joan C. Tronto, “The Nanny Question”, Hypatia, 17: 2 (2002), 34-51 (p. 37).

${ }^{41}$ Scheftel, p. 252.

42 Ibos, p. 229.
} 


\section{Julie Rodgers}

Louise's entire existence has been one of giving care to others but never receiving it, of having to respond to "la voix des autres, de tous ceux qui lui ont donné des ordres, des conseils, qui ont proféré des injonctions" (p. 206). As the novel draws to a close, the repeated lack of opportunities to receive care, or even practice self-care, have given rise to a crippling bitterness in Louise: "Une haine monte en elle. Une haine qui vient contrarier ses élans serviles [...]. Une haine qui brouille tout. [...] Hantée par l'impression d'avoir trop vu, trop entendu de l'intimité des autres, d'une intimité à laquelle elle n'a jamais eu droit. Elle n'a jamais eu de chambre à elle" (p. 159). There is also the awareness of her own low social class that comes into sharp relief when she is at the Massé's apartment and which is exacerbated by the affronts, albeit unintentional, to her poverty that she experiences at the hands of her employers. Paul and Myriam mock her fear of wasting food, which clearly stems from her own economic struggles: "Cette lubie de Louise, cette phobie de jeter la nourriture, commence par les faire rire. La nounou racle les boîtes de conserves, elle fait lécher les pots de yaourt aux enfants. Ses employeurs trouvent cela ridicule" (p. 161). When Mila loses a cardigan at school, Louise makes every possible effort to recover it. Myriam, however, simply replaces it with a new one, an action that provokes an outburst of anger from Louise: “C'était bien la peine que je m'épuise à le chercher. Et qu'est-ce que ça veut dire? On se fait voler, on ne prend pas soin de ses affaires mais ce n'est pas grave, maman va racheter un gilet pour Mila?" (p. 172). Scheftel makes a pertinent observation that explains Louise's reaction, remarking that "in some uppermiddle-class communities, individual items of a young child's wardrobe might cost more than a nanny's weekly salary, potentially encoding a message that a nanny's services could be worth less or financially trumped by material possessions". ${ }^{43}$ That Louise is ashamed of her poverty and low social-class is perhaps the reason why she relies so heavily on make-up and perfecting her appearance, as a disguise of sorts for who she really is. Louise's financial precarity is a source not simply of personal embarrassment but also of immense psychological stress. She despises the apartment she rents and the area in which it is situated: "Quand elle ouvre les portes de son studio, ses mains se mettent à trembler. [...] Un magma informe, une douleur lui brûlent les entrailles et elle a du mal à se retenir de hurler" (p. 86). Due to the mountain of debts she can no longer ignore, Louise becomes extremely anxious about her future and the very real possibility of homelessness (p. 153). Alongside this is the additional worry caused by the approach of old age and the increased "frais médicaux" she will inevitably face but will not be able to afford (p. 159).

In addition to the situational circumstances that no doubt impinge on Louise's ability to care, there are also some disturbing intrapsychic factors that must be taken into consideration. As the novel unfolds, it appears that Louise has a propensity towards violence that she manages to suppress for the most part. Not only does she

\footnotetext{
${ }^{43}$ Scheftel, p. 623.
} 
show a tendency towards violent behaviour, there is also the suggestion that she derives pleasure from it. Of her relationship with her husband, we are informed that "la colère de son époux lui faisait peur mais elle devait aussi reconnaître que, parfois, cela l'excitait" (p. 97). Then there is the incident where she hides from the children in the apartment and deliberately prolongs their distress for her own amusement: "Elle les regarde comme on étudie l'agonie du poisson à peine pêché, les ouïes en sang, le corps secoué de convulsions" (p. 51). Louise's most perturbing display of violence in the novel, however, is her vicious attack on her adolescent daughter Stéphanie following the latter's expulsion from school:

[E]lle s'est mise à rouer Stéphanie de coups. Elle l'a frappée sur le dos d'abord, de grands coups de poing qui ont projeté sa fille à terre. L'adolescente, recroquevillée, criait. Louise a continué de frapper. Toute sa force de colosse s'est déployée et ses mains minuscules couvraient le visage de Stéphanie de gifles cinglantes. Elle lui tirait les cheveux, écartait les bras dont sa fille entourait sa tête pour se défendre. Elle la tapait sur les yeux, elle l'insultait, elle l'a griffée jusqu'au sang. Quand Stéphanie n’a plus bougé, Louise lui a craché au visage.

That Louise should treat her own daughter with such brutality and yet engage in the care of another family's children raises the question of whether her work as nanny could be a form of atonement for past actions or, perhaps more worryingly, whether it is a direct consequence of what Downing delineates as the "extra [and overwhelming] emotional labour of [constantly] being for the other". ${ }^{44}$ It also adds another layer to the novel's representation of "deviant care", expanding it from the murder of the Massé children to include the neglect and abuse of Louise's own daughter too. Slimani thus invites the reader to reflect on the debilitating consequences for biological children when maternal caregiving has to be directed elsewhere, usually for financial reasons.

A further intrapsychic factor that emerges from the character portrait of the nanny and which no doubt negatively affects her caregiving, is Louise's unstable mental health. Her mind shifts between manic desires and morbid thinking. She becomes consumed with the fantasy of a new baby whom she believes will "save" her:

L'obsession de l'enfant tourne à vide dans sa tête. Elle ne pense qu'à ça. Ce bébé qu'elle aimera follement, est la solution à tous ses problèmes. [...] Il protègera la place de Louise en son royaume. [...] Ce bébé, elle le désire avec une violence de fanatique, un aveuglement de possédée. Elle le veut comme elle a rarement voulu, au point d'avoir mal, au point d'être capable d'étouffer, d'anéantir tout ce qui se tient entre elle et la satisfaction de son désir.

44 Downing, Selfish Women, p. 123. 


\section{Julie Rodgers}

At other times, she is invaded by dark thoughts of death and killing: "Il faut que quelqu'un meure pour que nous soyons heureux. Des refrains morbides bercent Louise $^{45}$ quand elle marche" (p. 213). In addition to the mania and the aberrant thoughts, we are told that Louise "rit moins", has "peu d'entrain" (p. 211) for the children's games and that "ses idées se brouillent" and "son malaise s'amplifie" (p. 158). There is much to suggest that this is a downturn in Louise's mental health that is now spiralling out of control: "[E]lle est habitée par un hurlement intérieur qui lui déchire les entrailles" (p. 158). However, as mentioned above, Slimani does not allow the reader to focus exclusively on this aspect of Louise. As such, the information that Louise has previously been diagnosed as suffering from "mélancolie délirante" (p. 159), as well as having been admitted to hospital once before for this very reason (p. 226), is passed over quite quickly. Rather than encourage the reader to fixate on unearthing the one reason that will explain the infanticide, Slimani paints a more holistic picture of the killer nanny in a bid to incite much broader reflection on the experience of caregiving and the reasons why abuse and deviance may arise within a relationship that is initially positive.

\section{Conclusion}

Writing for The Nation at the turn of the millennium, Deborah Stone sets out the case for a "care movement". Care, she informs us, "is as essential as the air we breathe", because "dependence is the human condition" " And yet, Stone reminds us, we do not always care for our carers, we do not think about them as individuals with their own struggles or, indeed, the very difficult and stressful nature of the work that they carry out; "caregiving is a class issue", Stones inisists, performed by the most vulnerable in society. As we have seen in relation to Chanson douce, poverty is a major factor that interferes with the quality of caregiving that the nanny can offer. With no stable home, a mountain of debts, an ingrained sense of inferiority, a life spent working in low-paid employment often without due recognition and no sense of security for the future, there is no doubt that Louise's care-work suffers as a direct result of her precarious social status.

Interrelated with the power dynamics of class at play in the novel is the imperative to care and the issue of gender. As Downing astutely observes, women are socialized from a young age into a maternal/caregiving form of femininity that leaves little space for the pursuit of self-interest. A woman's capacity to care is seen as "nature" and, indeed, is demanded of her. ${ }^{47}$ This biological essentialization of the ethics of care, of course, conceals the dangers and compromises involved in pursuing

\footnotetext{
45 This quotation reminds us once more of the ironic reference to a gentle lullaby in the title of the novel.

46 Deborah Stone, 2000, <https://www.thenation.com/article/archive/why-we-need-caremovement/>, accessed 06/02/2020.

${ }^{47}$ Downing, Selfish Women, pp. 101-102.
} 
such a selfless mode of being as well as the detrimental impact that it can have on female self-perception. In addition, the idea that care is innate to women further stresses the invisibility of the often challenging and oppressive reality of the labour. In the case of Chanson douce, the stark lack of possibilities for Louise to exist outside of her role as nanny gives rise to an unhealthy relationship with those for whom she cares. Louise becomes wholly dependent on other people needing her and views her survival as being contingent on her position as caregiver in the Massé household. Once her sense of security is in jeopardy, the descent into deviant care is almost irreversible. One could argue that the murder of the children and her attempted suicide is a bid to secure her role as their nanny beyond life, a refusal of their separation. However, the aim of this article is not to elicit unequivocal empathy for the killer nanny and thus risk minimizing the seriousness of Louise's actions. Rather, through close analysis of the nanny figure and the intricate web of circumstances that can impair her caregiving, I hope to have demonstrated the ways in which Leïla Slimani, through a tale of care gone tragically awry, exhorts the reader to think more ethically about the treatment of these women in society and the pressures they face.

Maynooth University, Ireland 
Reproduced with permission of copyright owner. Further reproduction prohibited without permission. 